medRxiv preprint doi: https://doi.org/10.1101/2022.01.16.22269389; this version posted January 18, 2022. The copyright holder for this preprint (which was not certified by peer review) is the author/funder, who has granted medRxiv a license to display the preprint in

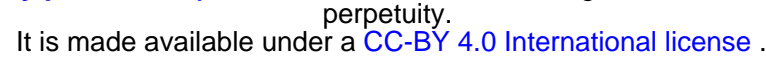

\title{
Time to commencement of effective treatment in patients with drug-resistant tuberculosis diagnosed in the Torres Strait / Papua New Guinea cross-border region
}

\author{
Foster, $\mathrm{J}^{1,2,3}$., Mendez, $\mathrm{D}^{4}$., Marais, $\mathrm{B}^{5}$., Peniyamina, $\mathrm{D}^{6}$., McBryde, E.S. ${ }^{1,2,3}$ \\ ${ }^{1}$ Australian Institute of Tropical Health and Medicine, Townsville, Queensland Australia \\ jbelle.foster@my.jcu.edu.au; diana.mendez@jcu.edu.au; emma.mcbryde@jcu.edu.au \\ ${ }^{2}$ James Cook University College of Medicine and Dentistry, Townsville, Queensland Australia \\ jbelle.foster@my.jcu.edu.au; emma.mcbryde@icu.edu.au \\ ${ }^{3}$ Torres and Cape Tuberculosis Control Unit, Thursday Island, Queensland Australia \\ jbelle.foster@my.jcu.edu.au, emma.mcbryde@jcu.edu.au \\ ${ }^{4}$ James Cook University Division of Tropical Health and Medicine, Townsville, Queensland Australia \\ diana.mendez@jcu.edu.au \\ ${ }^{5}$ Sydney Institute for Infectious Diseases and Biosecurity (Sydney ID), Westmead, New South Wales \\ Australia Ben.Marais@health.nsw.gov.au \\ ${ }^{6}$ Cairns Tropical Public Health Service, Cairns, Queensland Australia \\ Dunstan.Peniyamina@health.qld.gov.au
}

\begin{abstract}
Introduction

Delays between self-reported symptom onset and commencement of effective treatment contribute to ongoing tuberculosis (TB) transmission; this is a particular concern in patients with drug-resistant (DR)-TB. We assessed improvements in time to commencement of effective treatment in patients diagnosed with DR-TB in the Torres Strait region.
\end{abstract}

\section{Methods}

All laboratory-confirmed DR-TB cases diagnosed in the Torres Strait between 1 March 2000 and 31 March 2020 were reviewed. We assessed the total time from self-reported onset of symptoms to effective treatment commencement in different programmatic time periods. Pairwise analyses and time to event proportional hazard calculations were used to explore the association between delays in median time to effective treatment, and selected variables. Data were further analysed to examine predictors of excessive treatment delay.

\section{Results}

The median number of days from self-reported onset of symptoms to effective treatment commencement was 124 days. Between 2006 and 2012, most (57\%) cases exceeded this 'grand median' while the median 'time to treat' in the most recent time period (2016-2020) was significantly reduced to 29 days $(p<0.001)$. Although there was a reduction in the median 'time to treat' with the introduction of Xpert MTB/RIF (135 days pre-Xpert vs 67 days post-Xpert) this was not statistically significant ( $p$ 0.07). Establishment of the Torres and Cape TB Control Unit on Thursday Island (2016-2020) when compared with previous TB programs (2000-2005 $p<0.04 ; 2006-2012 p$ $<0.001$ ) and case type (new vs past treatment; $p 0.02$ ) were significantly associated with reduced tPeatimlhen pregringty. reports new research that has not been certified by peer review and should not be used to guide clinical practice. 
medRxiv preprint doi: https://doi.org/10.1101/2022.01.16.22269389; this version posted January 18, 2022. The copyright holder for this preprint (which was not certified by peer review) is the author/funder, who has granted medRxiv a license to display the preprint in

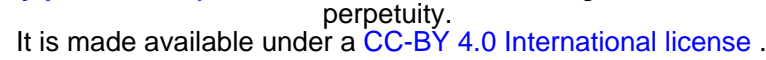

\section{Conclusion}

Minimising TB treatment delay in remote settings like the Torres Strait / Papua New Guinea crossborder region requires effective decentralised diagnosis and management structures. Study results suggest that the establishment of the Torres and Cape TB Control Unit on Thursday Island helped to improve time to treatment for TB patients in the region. Possible contributing factors include better symptom recognition, TB education, cross-border communication and patient-centred care.

\section{Introduction}

Tuberculosis (TB) remains a disease of public health significance, with an estimated 10 million cases diagnosed in 2019 (1). Australia's TB incidence is considered low at 5.5/100,000 population (2) however, TB disproportionately affects Indigenous Australian populations, and the incidence rate in the Torres Strait in 2014 was 107/100,000 population based on Australian Bureau of Statistics 2011 Census population data. In Papua New Guinea (PNG), TB is the leading cause of death from an infectious agent, with a TB case notification rate of 674/100,000 population in the Western Province in 2016 (3). In 2014, the PNG National Department of Health declared Daru Island in the Western Province a 'hot-spot' as of approximately 500 cases of TB diagnosed on the island each year, one in ten TB were multidrug-resistant (MDR) (4).

Disease control is impeded in patients with drug-resistant (DR)-TB. Drug-resistance can be community-acquired, or as a result of irregular or interrupted treatment. It can also occur due to inadequate drug regimens or malabsorption of treatment $(5,6)$. Treatment regimens for both rifampicin resistant (RR) and MDR-TB which is TB that is resistant to both isoniazid and rifampicin, require second-line drugs to treat which are more expensive, toxic, and time-consuming (7). A major factor of treatment success for DR-TB patients is prompt diagnosis and commencement of effective sustained treatment (6). Delays in treatment commencement can result in high bacillary load which can contribute to the infectious pool, hence the importance of early effective treatment commencement (8). In settings with excessive delays from symptom onset to treatment commencement, higher drug-resistance is expected (9).

The Australian National TB Advisory Committee considers time to effective treatment commencement to be one of the most important markers of effective TB control programs (10). Although there is no global consensus on how to define excessive delay from self-reported symptom onset to treatment commencement, any delay impedes the primary purpose of TB programs which is to commence patients on treatment as soon as possible to minimise transmission risk $(11,12)$. Delays may occur before any interaction with the health system, owing to reduced health-seeking behaviours due to poor knowledge, distrust or impediments. Some delays occur after interaction with the health service, particularly diagnostic delays when TB is not considered in the differential diagnosis, and others are due to the TB diagnostic service itself such as availability of Xpert, other laboratory facilities, radiology and treatment $(13,14)$. Each of these delays can be addressed by TB control units (10).

Geographical and geopolitical challenges in the Torres Strait / PNG region create health care disparities which affect diagnosis, referral pathways, treatment and management of TB patients in the Torres Strait Protected Zone (TSPZ). Since the ratification of the Torres Strait Treaty in 1985, free bidirectional movement has been allowed for traditional, family, economic and trade purposes in 
medRxiv preprint doi: https://doi.org/10.1101/2022.01.16.22269389; this version posted January 18, 2022. The copyright holder for this preprint (which was not certified by peer review) is the author/funder, who has granted medRxiv a license to display the preprint in

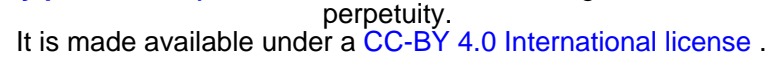

the TSPZ between 13 PNG Treaty villages in the Western Province and 13 adjacent Australian Torres Strait Islands $(15,16)$. As a result of this international agreement, there has been free cross-border movement of TB in the region from both Treaty and non-Treaty villagers. Primary transmission of TB and the rise of drug-resistance are cause for concern for at-risk Australian and PNG border communities (17). The Torres Strait Treaty does not include access to Australian healthcare for PNG villagers living adjacent to the Australian border, despite the 4.7 kilometre stretch of water separating the two countries (refer to figure 1). However, in response to the urgent nature of some healthcare needs, Queensland Health provides humanitarian aid to those most in need as well as providing triaging and point of care diagnostic services.

Optimising models of care for TB patients living in the Torres Strait / PNG international border region has been challenging and the programmatic TB response in the remote has evolved over time (refer to figure 2). Although Torres Strait and PNG cross-border communities are subject to a similar TB risk they do not have access to the same level of health care (18). In Queensland on the Australian side of the border, high-risk screening and passive TB case finding is standard practice whereby cases are diagnosed post-investigation of TB-related symptoms or incidentally while other medical conditions are being investigated $(10,19)$. During the study period, PNG nationals requiring TB work-up who did not present to an Australian health facility were required to travel to Daru General Hospital, located at least two hours away by small motorised boat (at a cost of AUD\$240) (20). The region's geography and associated travel costs renders accessing TB health care services prohibitive for PNG nationals residing adjacent to the TSPZ, where the Multi-dimensional Poverty Index is estimated to be 0.32 (21). Over the past 20 years, these mechanisms have affected time to treatment commencement for PNG residents with TB living adjacent to the Australian border. The consequences are sustained transmission risk and rapid growth of DR-TB on both sides of the border.

Time from self-reported onset of symptoms to effective treatment commencement has not previously been investigated in this particular context. This study aimed to explore total time from self-reported onset of TB symptoms to effective treatment commencement for all DR-TB cases diagnosed in the Torres Strait / PNG border region over two decades. This study will identify factors associated with longer than expected delays as well as discuss programmatic interventions that may have contributed to reduced treatment delays over time. As DR-TB is an established risk in the Torres Strait / PNG border, this study may help to improve programmatic management of TB in the region to the benefit of both Australian and PNG health care systems and local communities.

\section{Methods}

\section{Design}

This retrospective cohort study included patients diagnosed in the Torres Strait Islands with any form of DR-TB (including mono and multi) and those with pulmonary, extrapulmonary, smear negative and smear positive diagnoses between 1 March 2000 and 31 March 2020.

\section{Ethics}

This study was conducted with the ethical approval from the Far North Queensland Human Research Ethics Committee (HREC) (HREC/17/QCH/74-1157), the Chair of James Cook University HREC (H7380) and with Public Health Act authorisation (QCH/36155 - 1157).

\section{Study Population}

All residents of the Australian Torres Strait Islands that received health care in a Primary Health Centre (PHC) or Thursday Island Hospital in the Torres Strait, and PNG patients that received health 
medRxiv preprint doi: https://doi.org/10.1101/2022.01.16.22269389; this version posted January 18, 2022. The copyright holder for this preprint (which was not certified by peer review) is the author/funder, who has granted medRxiv a license to display the preprint in

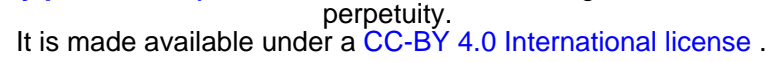

care within the TSPZ, including children, diagnosed with microbiologically confirmed DR-TB were included in the study.

Sputum and other histological samples were collected in the Torres Strait Islands and sent via sea and air to a WHO-designated Supranational Reference Laboratory, the Queensland Mycobacterium Reference Laboratory (QMRL) (22) (refer to figure 1). Confirmation of DR-TB diagnosis was confirmed by culture and phenotypic drug susceptibility testing (DST) pre-November 2010, or by Xpert, culture and DST post-November 2010 (22).

\section{Definitions}

The sample size is based on 133 cases with DR-TB, with 113 experiencing the event (known effective treatment commencement).

Effective treatment was defined as the implementation of appropriate second-line TB treatment for RR/MDR-TB cases and appropriate TB treatment for other drug-resistant cases, whether this was programmatic / empiric or personalised.

Time to event was defined as the sum in days of the following three distinct intervals:

1. Patient Delay (the time from self-reported TB symptom onset to presentation at a health facility in the Torres Strait)

2. Health System Delay (the time from presentation at a health facility to being diagnosed with TB)

3. Treatment Delay (the time from diagnosis to event - effective treatment commencement or transfer out/death).

As not all participants commenced treatment, the data are right censored. The 20 censored cases were observed in the study to pass through the sum (in days) of patient delay and health system delay - time from self-reported onset of symptoms to diagnosis.

Diagnosis year group reflects the changes in programmatic TB responses in the remote Torres Strait / PNG international border that occurred over time (refer to Figure 2).

Case type was defined as either a new case, or relapsed case following full or partial treatment in Australia or overseas. These were analysed as independent events. Four patients who had previously received full or partial treatment were diagnosed twice in this study. Self-reported onset of symptoms did not overlap for any of these four patients.

\section{Data Collection}

Clinical and demographic data were sourced from the Queensland Notifiable Conditions System (NoCS), and drug-resistance for each case was verified in Queensland Health's laboratory results software AUSLAB. Case notifications were cross-checked between NoCS and AUSLAB and one case of DR-TB identified from NoCS but not from AUSLAB, was removed from the study.

The date of symptom onset and treatment commencement in NoCS was cross-checked against selfreported symptom onset date and treatment commencement documented in patient charts, Queensland Health state-wide patient database, The Viewer (23), and in Torres and Cape Hospital and Health Service (North) patient database, Best Practice (24). As NoCS relied on retrospective submissions of case notification data throughout the study period, original or copies of handwritten progress notes in patient charts, and referrals and progress reports in The Viewer and Best Practice were considered the sources of truth for this study for symptom onset and treatment 
medRxiv preprint doi: https://doi.org/10.1101/2022.01.16.22269389; this version posted January 18, 2022. The copyright holder for this preprint (which was not certified by peer review) is the author/funder, who has granted medRxiv a license to display the preprint in

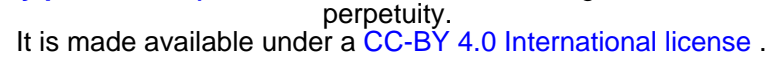

commencement. If this evidence was not available, the date of symptom onset and treatment commencement in NoCS was used. For data pertaining to 2016 and onwards, a combination of NoCS, The Viewer, Best Practice and two Excel spreadsheets specifically used to manage patient data for residents of the Torres Strait Islands, and PNG patients diagnosed with TB, were used to ascertain self-reported date of onset of symptoms and date of treatment commencement for each case.

\section{Data Analyses}

All statistical analyses were performed using IBM SPSS Statistics, version 27 (2020, Armonk, New York, United States).

Frequencies and percentages were calculated for categorical variables including treatment event (effective treatment commencement or transfer out / death), visa status, case type, rifampicin resistant TB, multidrug-resistant TB and gender.

Tests for normality were performed for mean, median, skewness and kurtosis, and visual inspections of histograms were reviewed. Assumptions for normality were violated and data were not normally distributed, hence descriptive statistics using counts, median, and interquartile range were used to demonstrate differences in the total time to effective treatment commencement across the four different time periods. When determining median days to effective treatment commencement, patients who did not commence known treatment and were transferred out or died, were removed from analyses, hence time to treatment outcomes should be interpreted as conditional on treatment commencement.

To determine any association between advanced diagnostic technology implementation in Queensland from November 2010, a non-parametric independent samples Median Test for $\mathrm{k}$ samples was used. The dependent variable was total time in days to known treatment commencement and the independent categorical variables were pre and post-Xpert. Patients that did not commence effective TB treatment due to death or transfer out were removed from the analyses.

Independent samples median test of frequencies was used to both identify the grand median, and to demonstrate frequencies above and below the median days to effective treatment commencement across different time periods. Post-hoc analyses were performed using pairwise comparison to determine the differences of median delays across the four different time periods, reflecting different programmatic management types. The dependent variable was total time to event (symptom onset to effective treatment commencement), and two time periods were compared at a time using pairwise comparison. Statistical significance was set at $p<0.05$. Due to the relatively small sample size and to counter a potential Type 1 error that may occur when multiple analyses are performed on the same dependent variable, a Bonferri correction was applied (25). The alpha was lowered by taking the unadjusted $p$-value and multiplying it by the number of pairwise comparisons (25).

A time to event analysis was conducted using Cox proportional hazards regression where the dependent variable was "time to known effective treatment commencement". Independent variables included in both univariate and multivariate analyses in this model were visa status, case type, rifampicin resistance and gender. As visa status was a tri-level categorical variable, the reference group was defined as PNG Treaty visitor to allow a comparison between the two PNG levels (non-Treaty versus Treaty). A Cox proportional hazards regression plot was used to illustrate the time to known treatment commencement in days, stratified by case type (new versus previous full or partial treatment). 
medRxiv preprint doi: https://doi.org/10.1101/2022.01.16.22269389; this version posted January 18, 2022. The copyright holder for this preprint (which was not certified by peer review) is the author/funder, who has granted medRxiv a license to display the preprint in

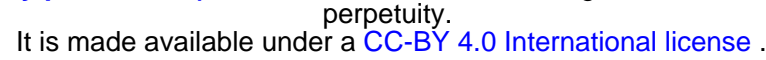

\section{Results}

\section{$\underline{\text { Descriptive Statistics }}$}

Table 1 shows that of 133 patients diagnosed with DR-TB between 2000 and 2020, 20\% had previously received full or partial TB treatment in Australia or overseas and $70 \%$ were resistant to rifampicin. The proportion of patients with MDR-TB overall who previously received full or partial treatment was 26\% (23/89 cases). Between 2000 and 2005, 100\% of DR-TB cases were new and of those, $71 \%$ were rifampicin resistant.

Table 2 demonstrates that the median time to effective treatment commencement for 113 patients increased after 2000 to 2005 (92 days; IQR 70-201) and peaked between 2006 and 2012 at 138 days (IQR 72-251). Reduction to 29 days (IQR 7-45) was observed between 2016 and 2020.

\section{$\underline{\text { Inferential Statistics }}$}

The independent samples median test (Figure 3) shows that the grand median time from selfreported TB symptom onset to known effective treatment commencement for DR-TB cases was 124 days. Figure 3 shows post-hoc pairwise analyses demonstrating a statistically significant difference between the "time to known effective treatment commencement" medians of patients in the diagnosis year groups 2000-2005 and 2016-2020 ( $p$ 0.04), and year groups 2006-2012 and 2016-2020 $(p<0.001)$. Frequencies of cases both above and below the median are illustrated in Figure 3 . Fiftyseven percent $(n=48)$ of cases diagnosed between 2006 and 2012 exceeded the median total time to effective treatment commencement. All other diagnosis year groups had greater numbers of participants below the median than above the median.

Table 3 demonstrates that post-Xpert, the median time from self-reported symptom onset to treatment commencement was 67 days and the pre-Xpert time to treat median was 135 days. An independent samples median test demonstrated that there was no statistically significant difference ( $p$ 0.07) between the total time to effective treatment for cases diagnosed pre-and and postimplementation of rapid diagnostic Xpert technology.

Table 4 shows that in the Cox proportional hazards regression univariate analysis, being an Australian resident (OR 2.401; $p$ 0.02) was a predictor of earlier effective treatment commencement, however in the multivariate analysis, the covariate of visa status was no longer significant ( $p 0.06)$. Case type emerged as a predictor of earlier effective treatment commencement in the univariate analysis (OR .557; $p$ 0.01) and was the sole predictor of earlier effective treatment in the multivariate (OR .542; $p$ 0.02) model.

Figure 4a shows the Cox proportional hazard plot for case type and total time to commencement of effective treatment. As can be seen in this figure, patients that had previously received full or partial treatment, demonstrated a more gradual slope to hazard (i.e., "time to known commencement of effective treatment"). Figure 4b shows the Cox proportional hazard plot for TB services provided by Cairns TB Control Unit and the Torres and Cape TB Control Unit. This figure shows that patients treated within the Cairns TB Control Unit, demonstrated a more gradual slope to hazard (i.e. "time to known commencement of effective treatment").

\section{Discussion}

In this study, the lengthy median delay from self-reported onset of symptoms to effective treatment commencement was 124 days. This is approximately four times more than the time to treat in metropolitan Victoria, Australia, where 33 days from symptom onset to treatment commencement 
medRxiv preprint doi: https://doi.org/10.1101/2022.01.16.22269389; this version posted January 18, 2022. The copyright holder for this preprint (which was not certified by peer review) is the author/funder, who has granted medRxiv a license to display the preprint in

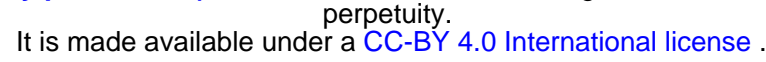

was deemed an acceptable delay (26). Even considering remoteness this key finding is still well above delays in other similar settings. A systematic review of 198 studies reported a pooled mean total delay of 88 days across low and middle-income countries in both urban and remote settings (11). Remoteness of the region, diagnostic services located on mainland Australia, access to pharmaceuticals for patients who commenced treatment in Australia and limited telecommunications with residents of Treaty and non-Treaty villages in PNG all remained unchanged throughout the study period, therefore variation of time to effective treatment are likely to be associated with other factors. Excessive delays between onset of symptoms and treatment commencement may contribute to ongoing transmission of TB in the region and TB programs should strive to reduce this time (14).

As low-level of health service coverage and lack of awareness of TB had previously been identified as factors extensively affecting time from onset of TB symptoms to treatment in other rural and remote settings (13), various programmatic initiatives were introduced by the Torres and Cape TB Control Unit. For example, culturally competent health promotion has been shown to increase knowledge and uptake of disease prevention strategies in culturally diverse communities (27). Initiatives introduced by the Torres and Cape TB Control Unit included specific onboarding and opportunistic education for staff, and development and distribution of linguistically and culturally appropriate TB education materials. These initiatives may have been contributing factors to the decrease in time to effective treatment ( 29 days) from 2016 to below the level considered acceptable in metropolitan Victoria (33 days) (26). These contributing factors may require further investigation to better understand their effect on time to treatment.

Changes to the management of TB in the region over time may help to explain a near 5 -fold decrease in the median time to treat between 2006 to 2012 and 2016 to 2020. By 2012, the Daru TB Program in PNG, supported by the Australian Government, had developed capacity to manage both fully-susceptible and DR-TB cases (20). Measures introduced in the region from 2014 and programmatic changes from 2016 may have also contributed to a reduction in median time from onset of symptoms to effective treatment commencement. From 2014-2016, Australian Commonwealth funding supported the delivery of TB-clinician-led initiatives to enhance TB knowledge amongst local communities and healthcare facilities on both sides of the international border $(18,28-30)$. This enhanced knowledge of the basic features of TB may have assisted in reducing the time from self-reported onset of symptoms to presentation at a health facility.

During this time, Australian Commonwealth funding also supported a data integrity project (31) to gather all historic PNG patient charts located on Australian Torres Strait Islands and patient data contained in an electronic medical record used prior to 2011, Holt's database (24). Data migration into Best Practice software enabled clinicians to access patient information in a single electronic database. As a result of the cross-border data integrity project, from 2015, all PNG Nationals presenting with signs and symptoms of TB to a PHC in the TSPZ have an electronic medical record. This initiative led to increased real-time visibility of all patients in the TB care pathway, provided access to information about past TB diagnoses and past contact history dating back to the 1950's, and allowed for identification and follow-up of previously treated cases.

Xpert can improve diagnostic capability by identifying rifampicin resistance in TB patients and reducing diagnosis to treatment commencement delays (32). Implementation of Xpert in Queensland, Australia in November 2010 improved the overall median delay to 67 days in this study, which was approximately half the median pre-Xpert, indicating that implementation of Xpert in the Torres Strait may help to further reduce time to effective treatment delays (33). Although the point- 
medRxiv preprint doi: https://doi.org/10.1101/2022.01.16.22269389; this version posted January 18, 2022. The copyright holder for this preprint (which was not certified by peer review) is the author/funder, who has granted medRxiv a license to display the preprint in

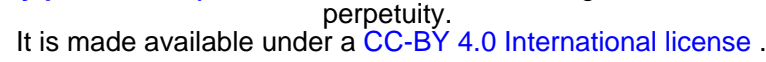

estimate difference pre and post-Xpert was large, there were additional temporal trends at the time and the difference pre- and post-Xpert was not statistically significant in this study.

Outreach TB specialist services provided by staff based in Cairns prior to 2016 may have influenced time to treatment commencement. Logistical issues and inclement weather at times affected the ability for Cairns-based TB clinicians to access the Torres Strait to review patients and commence them on treatment (20). In contrast, the Torres and Cape TB Control Unit established in 2016, hosts an ongoing presence of TB clinicians based in the Torres Strait and allowed for a continual service where suspected case management and treatment commencement could occur at any time.

In international border settings, strength is found in collaboration between international partners and where well-defined data sharing and referral agreements are in place (34). In collaboration with the Daru TB Program, the Torres and Cape TB Control Unit implemented new procedures to enhance recognition and streamline management of symptomatic patients (35). As a result of improved cross-border communication, programmatic rules and strategies were implemented from 2016 to strive for safe and ethical management of shared and referred patients. These included ensuring Daru's readiness to receive patients discharged from Australian hospitals, timely notification of microbiological and radiological results, an agreement regarding case notifications to avoid overreporting case numbers and sharing patient outcome data. This cross-border collaboration is evidenced in this study by known treatment commencement dates of 11/12 cases from 2016.

Traditional risk factors for delays from self-reported onset of symptoms to effective treatment commencement in other settings have included limited access to health facilities, rural or remote location, and distance to diagnostics $(11,13)$, however in this study, these factors apply for both new and previously treated cases. With few treatment supporters to administer Directly Observed Therapy in most of the PNG Treaty villages (36) and challenging cross-border communication pathways, previous compliance history and assurances of treatment compliance to follow were not always known. It should be emphasised that none of the variables in this study were highly predictive, which shows that there is huge individual patient variation in time to effective treatment commencement and no easily identifiable risk group. It is possible that treatment delays were more prominent in patients who had previously received some treatment due to a lack of information, patient counselling and education from past TB care providers (37). As previously treated patients may have had negative past treatment experiences thus delaying retreatment commencement, additional support for these patients is warranted (38).

To help minimise the economic burden and improve timely access for PNG patients receiving TB care in the Torres Strait between 2006 and 2012, the Cairns TB Control Unit initiated free transport for PNG Nationals accessing outreach specialist clinics on Saibai and Boigu Islands (refer to figure 1) however large numbers of patients failed to attend appointments (20). A previous study identified that of 73 PNG MDR-TB patients diagnosed in the Torres Strait, 15 were loss to follow up, and a further 25 had an unknown treatment outcome (20). A recent study conducted on Daru Island, reported longer delays to treatment commencement in symptomatic DR-TB household contacts presenting for TB screening when compared to symptomatic drug-susceptible household contacts (39). This suggests that there may be country-specific risk factors which require focused support for DR-TB patients and their close contacts. It may also indicate that previously treated patients may have reduced access, a reluctance to present or have different ideologies, prompting a need for additional support for this cohort of patients.

Potential reasons for delays in previously treated cases could be that TB patients may not have been aware that they could be diagnosed twice, may have been too sick to present earlier, or may not 
medRxiv preprint doi: https://doi.org/10.1101/2022.01.16.22269389; this version posted January 18, 2022. The copyright holder for this preprint (which was not certified by peer review) is the author/funder, who has granted medRxiv a license to display the preprint in

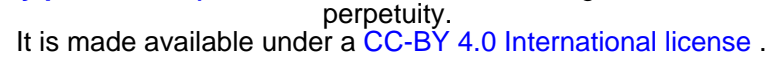

have been experiencing any signs and symptoms at all. It is also possible that pain and adverse reactions from injectables drugs used in previous management of DR-TB acted as a deterrent for patients or their close contacts presenting earlier (40), although it should be noted that only $45.8 \%$ of MDR-TB cases diagnosed in PNG nationals in this region between 2000 and 2014 received injectables (20). Nevertheless, as $80 \%$ of cases were new in this study, this suggests that there may be evidence of acquired drug-resistance in this population as a result of interrupted, irregular or inadequate treatment. Future qualitative research may assist TB programs in the Torres Strait to identify reasons why previously treated cases presented late in this region, and lead to improved and targeted strategies to improve early entry into the TB care pathway.

\section{Limitations}

It is possible that extensive delays in treatment commencement were attributed to repeated patient visits to PHCs, serviced by outreach Rural Generalist Practitioners. It is possible that some symptomatic patients did not immediately enter into the TB diagnostic pathway as PHC clinicians and Rural Generalist Practitioners may not have recognised TB as a leading differential diagnosis. As a satellite TB service was provided up until 2016, it is possible that TB clinicians were not notified of all symptomatic patients and Rural Generalist Practitioners prescribed a trial of broad-spectrum antibiotics to first rule out lower respiratory tract infections (41), as has been reported in other studies $(38,42)$. This study did not explore this possibility.

\section{Conclusion}

Minimising diagnostic and TB treatment delay is a global priority. Managing TB in rural and remote settings requires TB programs to strive for minimal diagnostic delay, early initiation of effective treatment, limited patient attrition with continuity of care, while recognising contextually-based hardships and health promotion needs of specific populations. The introduction of a decentralised TB management and control structure in the Torres Strait contributed to improved service delivery and a reduction in time to effective TB treatment commencement. It is imperative that good collaboration between the Torres and Cape TB Control Unit and the TB Program at Daru Hospital in PNG is sustained, with ongoing critical evaluation of factors associated with lengthy treatment delays or perceived barriers to symptom recognition, early diagnosis and effective treatment. 


\section{Results}

Table 1. Characteristics of drug-resistant tuberculosis patients diagnosed during different programmatic time period in the Torres Strait / Papua New Guinea cross-border region between 2000 and 2020

\begin{tabular}{|c|c|c|c|c|c|}
\hline & $\begin{array}{l}\text { All Cases 2000-2020 } \\
\qquad \begin{array}{c}(\mathrm{N}=133) \\
\mathbf{n}(\%)\end{array}\end{array}$ & $\begin{array}{c}2000-2005 \\
(N=14) \\
n(\%)\end{array}$ & $\begin{array}{c}2006-2012 \\
(N=96) \\
n(\%)\end{array}$ & $\begin{array}{c}\text { 2013-2015 } \\
(N=11) \\
n(\%)\end{array}$ & $\begin{array}{c}2016-2020 \\
(N=12) \\
n(\%)\end{array}$ \\
\hline \multicolumn{6}{|l|}{ Treatment group } \\
\hline Transfer out or death & $20(15)$ & $2(14)$ & $12(13)$ & $5(46)$ & $1(8)$ \\
\hline Treatment commenced & $113(85)$ & $12(86)$ & $84(88)$ & $6(55)$ & $11(92)$ \\
\hline \multicolumn{6}{|l|}{ Visa status } \\
\hline Australian resident & $9(7)$ & $0(0)$ & $2(2)$ & $4(36)$ & $3(25)$ \\
\hline PNG non-Treaty visitor & $38(29)$ & $5(36)$ & $28(29)$ & $1(9)$ & $4(33)$ \\
\hline PNG Treaty visitor & $86(65)$ & $9(64)$ & $66(69)$ & $6(55)$ & $5(42)$ \\
\hline \multicolumn{6}{|l|}{ Case type } \\
\hline New case & $107(81)$ & $14(100)$ & $72(75)$ & $10(91)$ & $11(92)$ \\
\hline $\begin{array}{l}\text { Full or partial treatment } \\
\text { overseas } \\
\text { Full or partial treatment }\end{array}$ & $21(16)$ & $0(0)$ & $20(21)$ & $0(0)$ & $1(8)$ \\
\hline Australia & $5(4)$ & $0(0)$ & $4(4)$ & 1 (9) & $0(0)$ \\
\hline \multicolumn{6}{|l|}{ Rifampicin resistant (RR) } \\
\hline Not RR & $40(30)$ & $4(29)$ & $34(35)$ & $1(9)$ & $1(8)$ \\
\hline $\mathrm{RR}$ & $93(70)$ & $10(71)$ & $62(65)$ & $10(91)$ & $11(92)$ \\
\hline \multicolumn{6}{|l|}{ Gender } \\
\hline Male & $58(44)$ & $6(43)$ & $44(46)$ & $3(27)$ & $5(42)$ \\
\hline Female & 75 (56) & $8(57)$ & $52(54)$ & $8(73)$ & 7 (58) \\
\hline Multidrug-resistant TB & $N=93$ & $N=10$ & $N=62$ & $N=10$ & $N=11$ \\
\hline Previous full or partial treatment & $23(25)$ & $0(0)$ & $21(34)$ & $1(10)$ & 1 (9) \\
\hline New case & $70(75)$ & $10(100)$ & $41(66)$ & $9(90)$ & $10(91)$ \\
\hline
\end{tabular}


medRxiv preprint doi: https://doi.org/10.1101/2022.01.16.22269389; this version posted January 18, 2022. The copyright holder for this preprint (which was not certified by peer review) is the author/funder, who has granted medRxiv a license to display the preprint in perpetuity.

It is made available under a CC-BY 4.0 International license.

Table 2. Time to commencement of effective drug-resistant tuberculosis treatment across different tuberculosis programmatic time periods in the Torres Strait / Papua New Guinea crossborder region between 2000 and 2020

\begin{tabular}{|c|c|c|c|c|}
\hline \multirow[t]{3}{*}{ Variable } & \multicolumn{4}{|c|}{ Time period* } \\
\hline & \multicolumn{3}{|c|}{ Services coordinated from Cairns } & Thursday Island \\
\hline & $2000-2005$ & $2006-2012$ & 2013-2015 & 2016-2020 \\
\hline $\mathbf{N}$ & 12 & 84 & 6 & 11 \\
\hline Mean & 133 & 204 & 103 & 38 \\
\hline Median & 92 & 138 & 67 & 29 \\
\hline IQR & $70-201$ & $72-251$ & $46-198$ & $7-45$ \\
\hline
\end{tabular}

*See Figure 2 for description of tuberculosis programmatic time periods in the Torres Strait / Papua New Guinea cross-border region between 2000 and 2020 
medRxiv preprint doi: https://doi.org/10.1101/2022.01.16.22269389; this version posted January 18, 2022. The copyright holder for this preprint (which was not certified by peer review) is the author/funder, who has granted medRxiv a license to display the preprint in

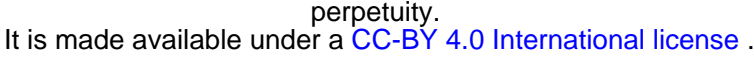

Table 3. Time to commencement of effective drug-resistant tuberculosis treatment pre and postXpert availability in the Torres Strait / Papua New Guinea cross-border region between 2000 and 2020

\begin{tabular}{|l|l|l|}
\hline & Pre-Xpert (2000-Oct 2010) & Post-Xpert (Nov 2010 - 2020) \\
\hline $\mathbf{N}$ & 75 & 38 \\
\hline Median & $135^{*}$ & $67^{*}$ \\
\hline Mean & 197 & 130 \\
\hline IQR & $73-248$ & $30-202$ \\
\hline
\end{tabular}

${ }^{*}$ p-value $=0.07$

Note. Xpert MTB/RIF assay was performed in Cairns or Brisbane 
medRxiv preprint doi: https://doi.org/10.1101/2022.01.16.22269389; this version posted January 18, 2022. The copyright holder for this preprint (which was not certified by peer review) is the author/funder, who has granted medRxiv a license to display the preprint in perpetuity.

It is made available under a CC-BY 4.0 International license.

Table 4. Univariate and multivariate Cox proportional hazards regression of variables associated with delayed 'effective treatment commencement' of drug-resistant tuberculosis in the Torres Strait / Papua New Guinea cross border region between 2000 and 2020. OR $>1$ implies a faster time to effective treatment commencement and $O R<1$ implies a slower time to effective treatment commencement.

\begin{tabular}{|c|c|c|c|c|}
\hline \multirow{2}{*}{$\begin{array}{l}\text { Variable } \\
N=133\end{array}$} & \multicolumn{2}{|c|}{ Univariate Analysis } & \multicolumn{2}{|c|}{ Multivariate Analysis } \\
\hline & OR & $p$ value & OR & p value \\
\hline Visa Status (categorical) & & 0.07 & & 0.1 \\
\hline $\begin{array}{l}\text { Australian resident vs PNG } \\
\text { Treaty visitor }\end{array}$ & 2.4 & 0.02 & 2.1 & 0.06 \\
\hline $\begin{array}{l}\text { PNG non-Treaty visitor vs } \\
\text { PNG Treaty visitor }\end{array}$ & 1.1 & 0.7 & 1.2 & 0.4 \\
\hline $\begin{array}{l}\text { Case Type (full/partial } \\
\text { treatment vs new case) }\end{array}$ & 0.6 & 0.01 & 0.5 & 0.02 \\
\hline $\begin{array}{l}\text { Rifampicin resistant (not } \\
\text { rifampicin resistant vs } \\
\text { rifampicin resistant) }\end{array}$ & 1.1 & 0.8 & 1.1 & 0.6 \\
\hline Gender (male vs female) & 1.4 & 0.1 & 1.3 & 0.2 \\
\hline
\end{tabular}

Note. PNG - Papua New Guinea

Effective treatment commencement - the implementation of appropriate second-line TB treatment for RR/MDR-TB cases and appropriate TB treatment for other drug-resistant cases, whether this was programmatic / empiric or personalised. 
medRxiv preprint doi: https://doi.org/10.1101/2022.01.16.22269389; this version posted January 18, 2022. The copyright holder for this preprint (which was not certified by peer review) is the author/funder, who has granted medRxiv a license to display the preprint in perpetuity.

It is made available under a CC-BY 4.0 International license .
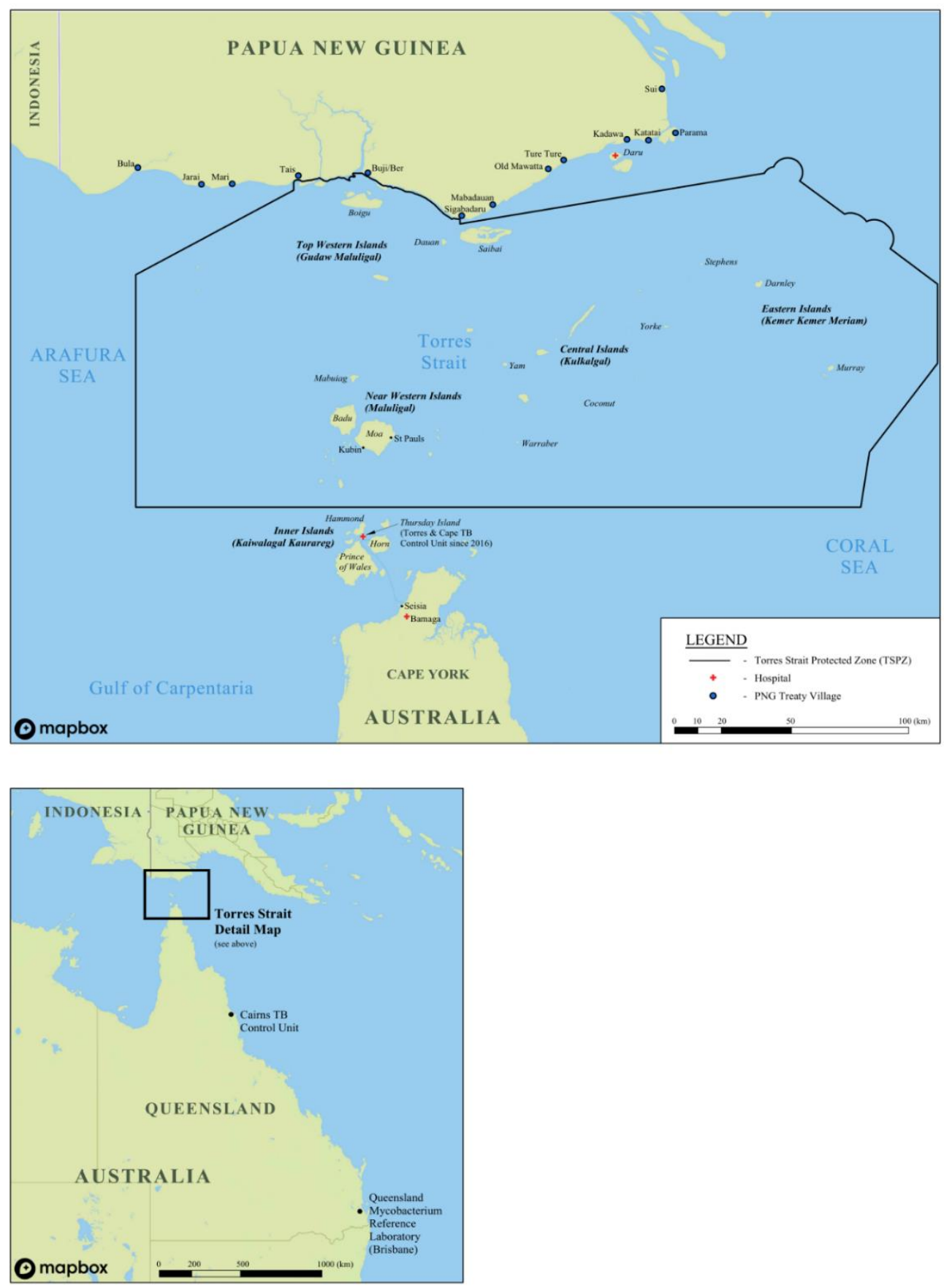

Figure 1. A) Map of the Torres Strait / Papua New Guinea border and B) relevant tuberculosis referral centres in Queensland, Australia. CC BY $4.0^{1}$ https://doi.org/10.6084/m9.figshare.16632823.v1

\footnotetext{
${ }^{1}$ Traditional inhabitants of the Torres Strait Islands in the Torres Strait Protected Zone and Treaty villages may travel across the international border for traditional purposes without visas, passports or health checks (15).
} 


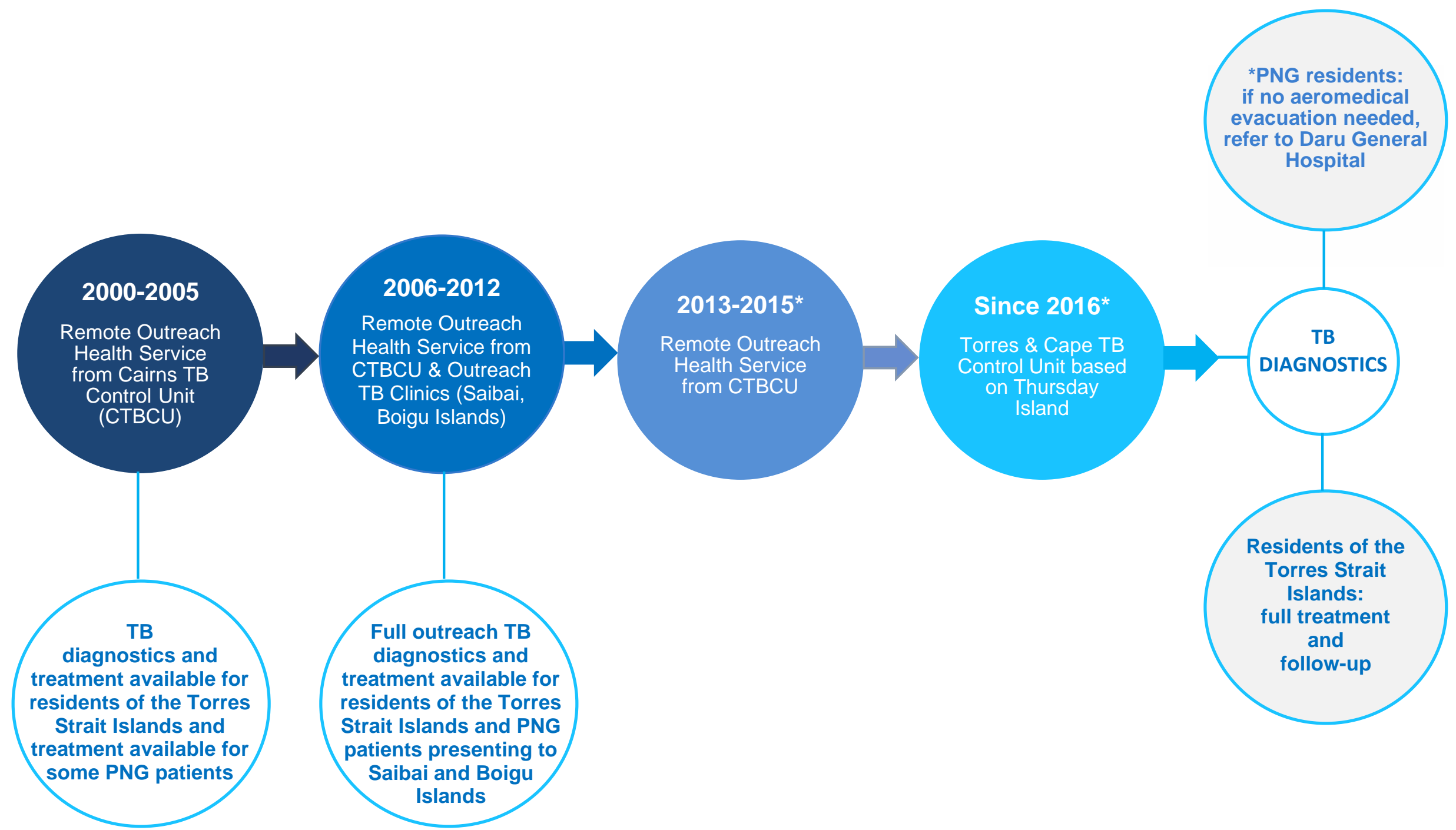

Figure 2. Description of the different tuberculosis (TB) programmatic time periods in the Torres Strait / Papua New Guinea (PNG) cross-border region between 2000 and 2020 CC BY 4.0 https://10.6084/m9.figshare.16834648 


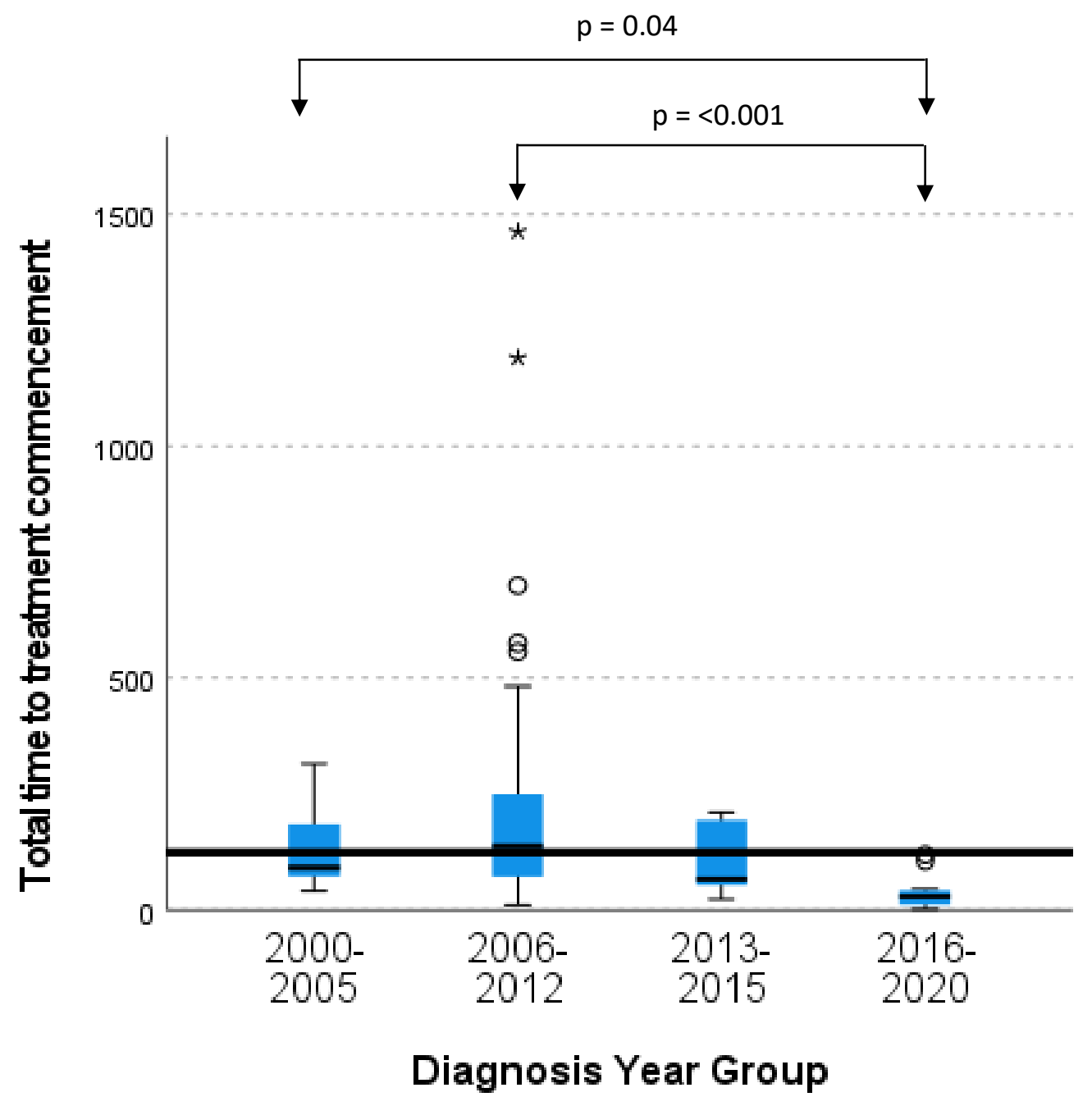

Grand median - the pooled median in days of all drug-resistant TB cases that commenced effective tuberculosis treatment

Significance values have been adjusted by the Bonferroni correction for the correct level of significance for multiple tests. Non-significant results are not shown.

Figure 3. Variability in median time to treatment commencement across different tuberculosis programmatic time periods in the Torres Strait / Papua New Guinea cross border region between 2000 and 2020 
medRxiv preprint doi: https://doi.org/10.1101/2022.01.16.22269389; this version posted January 18, 2022. The copyright holder for this preprint (which was not certified by peer review) is the author/funder, who has granted medRxiv a license to display the preprint in perpetuity.

It is made available under a CC-BY 4.0 International license.

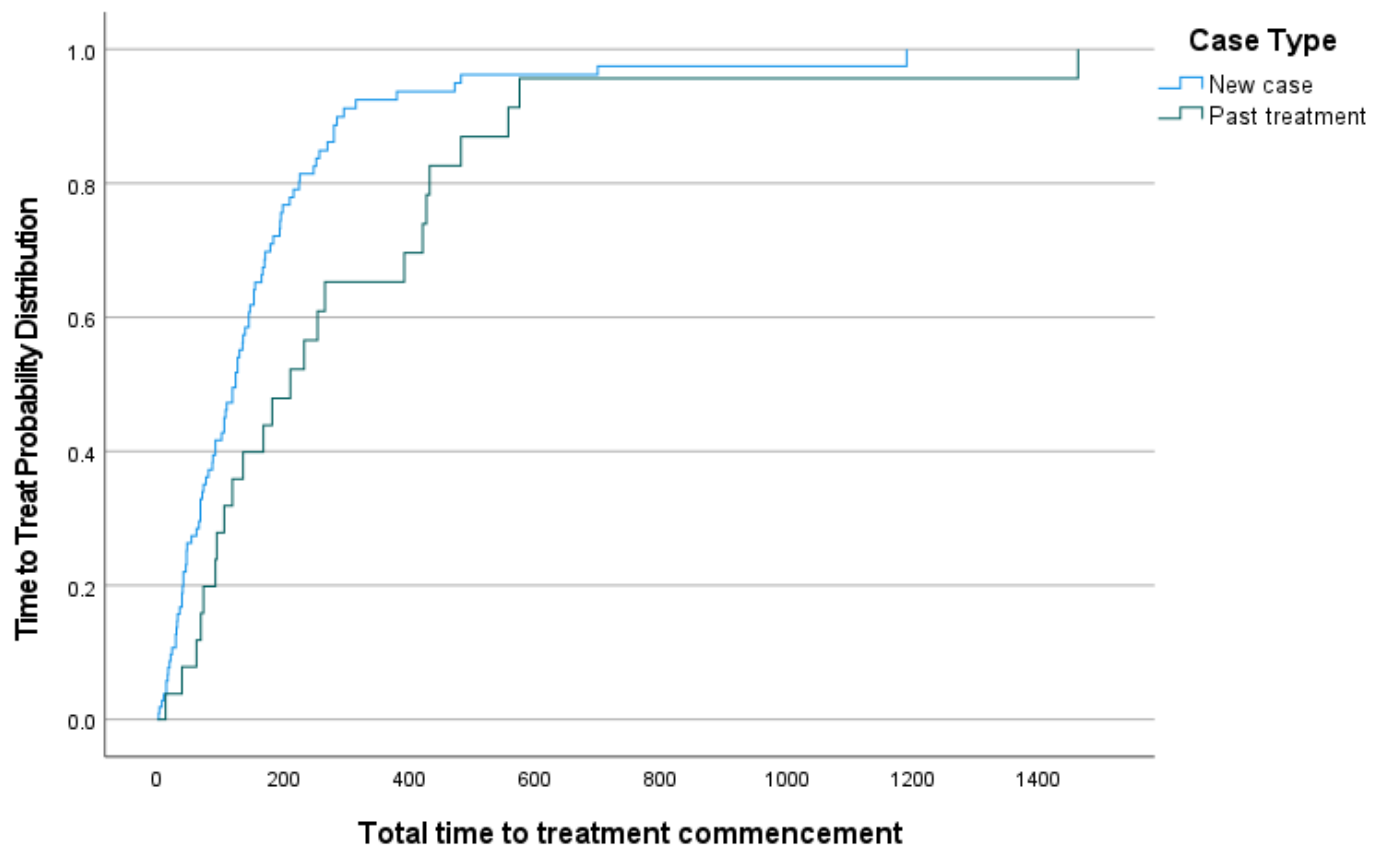

Note. New case - without any previous TB treatment; Past treatment - received full or partial TB treatment in the past

Figure 4a. Time to treat (days) stratified by 'new case' and 'past treatment' in the Torres Strait / Papua New Guinea cross border region between 2000 and 2020

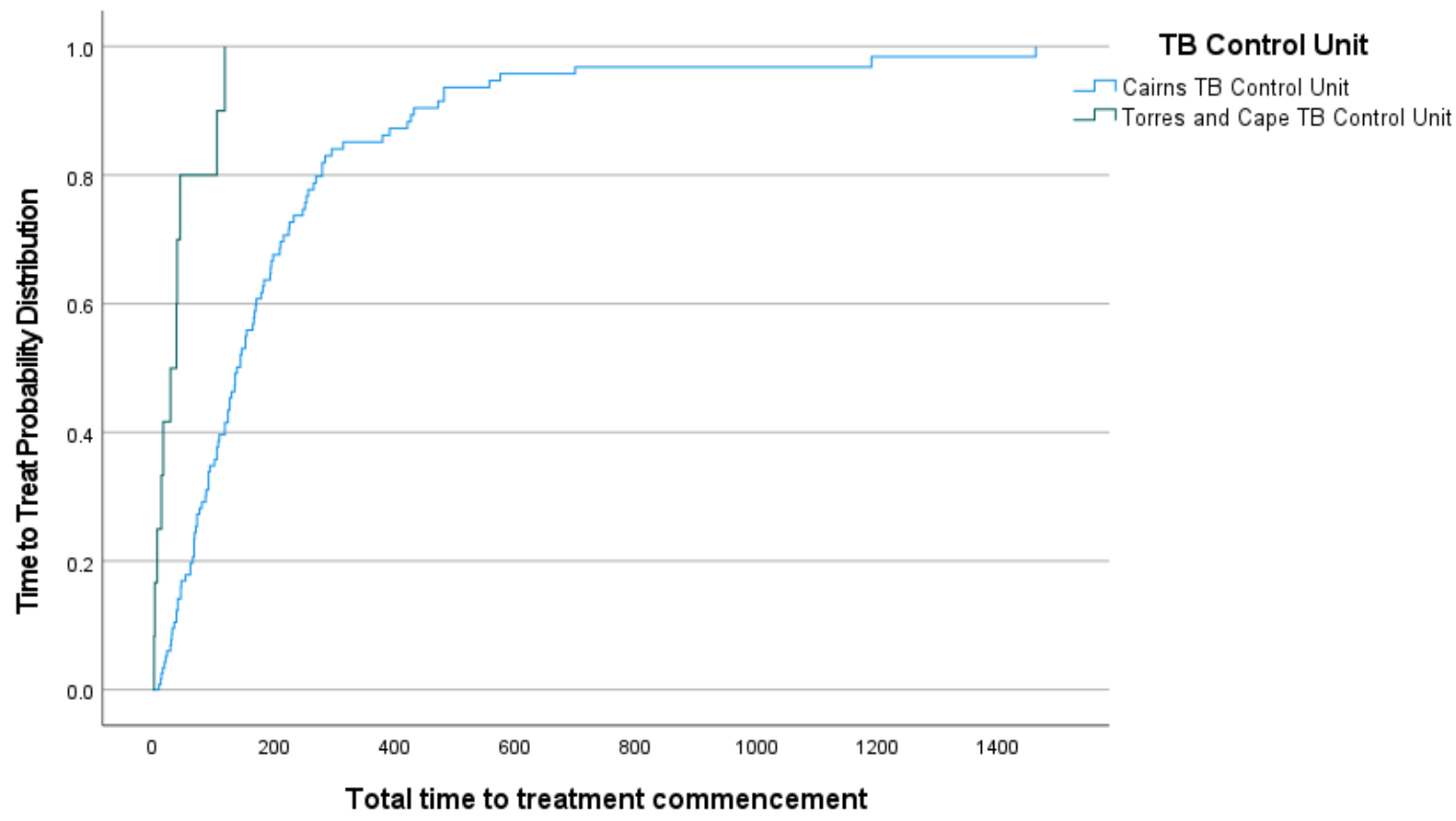

Figure 4b. Time to treat (days) stratified by TB services provided by the 'Cairns Tuberculosis Control Unit and Torres and Cape Tuberculosis Control Unit' in the Torres Strait / Papua New Guinea cross border region between 2000 and 2020 
medRxiv preprint doi: https://doi.org/10.1101/2022.01.16.22269389; this version posted January 18, 2022. The copyright holder for this preprint (which was not certified by peer review) is the author/funder, who has granted medRxiv a license to display the preprint in

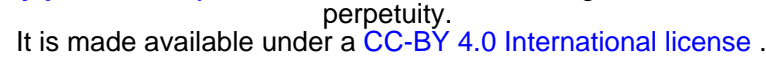

\section{REFERENCES}

1. World Health Organization. Global tuberculosis report. Geneva, Switzerland: World Health Organization.; 2020.

2. Viney K. The Australian tuberculosis risk factor survey Canberra, Australia: Australian National University; 2021

3. Aia P, Wangchuk L, Morishita F, Kisomb J, Yasi R, Kal M, et al. Epidemiology of tuberculosis in Papua New Guinea: analysis of case notification and treatment-outcome data, 2008-2016. Western Pacific Surveillance and Response Journal. 2018;9(2):9-19.

4. Taukarai R. Systematic screening for tuberculosis launches in Papua New Guinea: World Health Organization Western Pacific; 2018 [Available from: https://www.who.int/papuanewguinea/news/detail/13-02-2018-let-s-kick-tb-out-of-png. 5. Bento J, Duarte R, Brito MC, Leite S, M.R. L, Caldeira MdC., Carvalho A. Malabsorption of antimycobacterial drugs as a cause of treatment failure in tuberculosis. BMJ case reports. 2010.

6. Prasada R, Srivastavab DK. Multi drug and extensively drug-resistant TB (M/XDR-TB) management: Current issues. Clinical Epidemiology and Global Health. 2013;1(3):124-8.

7. World Health Organization. Global Report. Geneva, Switzerland: World Health Organization; 2018.

8. Chen Y, Yuan Z, Shen X, Wu J, Wu Z, Xu B. Time to Multidrug-Resistant Tuberculosis Treatment Initiation in Association with Treatment Outcomes in Shanghai, China. Antimicrobial Agents and Chemotherapy. 2018;62(4):e02259-17.

9. Lin X, Chongsuvivatwong V, Lin L, Geater A, Lijuan R. Dose-response relationship between treatment delay of smear-positive tuberculosis patients and intra-household transmission: a crosssectional study. Transactions of the Royal Society of Tropical Medicine and Hygiene.

2008;102(8):797-804.

10. National Tuberculosis Advisory Committee. The Strategic Plan for Control of Tuberculosis in Australia, 2016-2020: Towards Disease Elimination. The National Tuberculosis Advisory Committee for the Communicable Diseases Network Australia Communicable Diseases Intelligence. 2018;2019(43):1-19.

11. Bello S, Afolabi RF, Ajayi DT, Sharma T, Owoeye DO, Oduyoye O, Jasanya J. Empirical evidence of delays in diagnosis and treatment of pulmonary tuberculosis: systematic review and meta-regression analysis. BMC Public Health. 2019;19(820).

12. Lienhardt C, Rowley J, Manneh K, Lahai G, Needham D, Milligan P, McAdam KPWJ. Factors affecting time delay to treatment in a tuberculosis control programme in a sub-Saharan African country: the experience of The Gambia. International Journal of Tuberculosis and Lung Disease. 2001;5(3):223-39.

13. Belay M, Bjune, G., Ameni, G. Diagnostic and treatment delay among Tuberculosis patients in Afar Region, Ethiopia: A cross-sectional study. BMC Public Health. 2012;12:369.

14. Storla DG, Yimer S, Bjune GA. A systematic review of delay in the diagnosis and treatment of tuberculosis. Biomed Central Public Health,. 2008;8(15).

15. Department of Foreign Affairs. Australian Treaty Series 1985. In: Department of Foreign Affairs, editor. Canberra: Australian Government Publishing Service,; 1985.

16. Babbage R. The Strategic Significance of Torres Strait. Australian National University; 1990. 17. Gilpin CM, Simpson G, Vincent S, O'Brien TP, Knight TA, Globan M, Coulter C, Konstantinos A. Evidence of primary transmission of multidrug-resistant tuberculosis in the Western Province of Papua New Guinea. Medical Journal of Australia. 2008;188(3):148-52.

18. Torres Strait Cross Border Health Issues Committee meeting: Summary of discussion and key outcomes [press release]. Department of Foreign Affairs and Trade2016.

19. National Tuberculosis Advisory Committee. Essential components of a tuberculosis control program within Australia. Communicable Diseases Intelligence. 2014;38(4). 
medRxiv preprint doi: https://doi.org/10.1101/2022.01.16.22269389; this version posted January 18, 2022. The copyright holder for this preprint (which was not certified by peer review) is the author/funder, who has granted medRxiv a license to display the preprint in

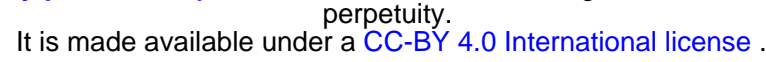

20. Baird T, Donnan, E., Coulter, C., Simpson, G., Konstantinos, A., Eather, G. . Multidrugresistant tuberculosis in Queensland, Australia: an ongoing cross-border challenge. International Journal of Tuberculosis and Lung Disease. 2018;22(2):206-11.

21. Busilacchi S, Butler JRA, Van Putten I, Maru Y, Posu J. Asymmetrical Development across Transboundary Regions: The Case of the Torres Strait Treaty Region (Australia and Papua New Guinea). Sustainability. 2018;10(11).

22. Queensland Health. Tuberculosis in Queensland. In: Queensland Department of Health, editor. Brisbane, Queensland,: Queensland Department of Health,; 2016. p. 1-26.

23. Queensland Health. Health Provider Portal Brisbane, Queensland2021 [Available from: https://hpp.health.qld.gov.au/.

24. Mclver L, Liu A. Streamlining chronic disease management in the Torres Strait: a review of current practice and recommendations for improvement. 13th National Rural Health Conference; 26 May; Darwin, Northern Territory2015.

25. International Business Machines Corporation (IBM). The calculation of Bonferroni-adjusted p-values 2020 [418157:[Available from: https://www.ibm.com/support/pages/calculationbonferroni-adjusted-p-values.

26. Pirkis JE, Speed BR, Yung AP, Dunt DR, Maclntyre CR, Plant AJ. Time to initiation of antituberculosis treatment. Tubercle and Lung Disease. 1996;77(5).

27. Henderson S, Kendall E, See L. The effectiveness of culturally appropriate interventions to manage or prevent chronic disease in culturally and linguistically diverse communities: a systematic literature review. Health and Social Care in the Community. 2011;19(3):225-49.

28. Torres and Cape Hospital and Health Service. TB education in PNG treaty villages. Cairns, Queensland2015.

29. Torres and Cape Hospital and Health Service. Tuberculosis in the Torres - the facts. 2015.

30. Torres Strait Cross Border Health Issues Committee meeting: Summary of discussion and key outcomes [press release]. Department of Foreign Affairs and Trade2015.

31. Australian Department of Health. Project Agreement for the management of Torres Strait/ Papua New Guinea cross border health issues In: Council of Australian Governments, editor. Canberra, Australia2012.

32. Center for Disease Control. A New Tool to Diagnose Tuberculosis: The Xpert MTB/RIF Assay. 2013.

33. Foster J, Marais B, Martin RL, Peniyamina D, Mendez D, Warner J, et al. Tuberculosis in the Torres Strait: the lady doth test too much. Rural Remote Health. 2021;21(1):6317.

34. Dara M, Sulis G, Centis R, D'Ambrosio L, De Vries G, Douglas P, et al. Cross-border collaboration for improved tuberculosis prevention \& care: Policies, tools \& experiences.

International Journal of Tuberculosis and Lung Disease. 2017;21(7):727-36.

35. Torres and Cape Hospital and Health Service. Procedure: Management of Papua New Guinea Nationals accessing healthcare within the Australian Islands of the Torres Strait Protected Zone, presumed to have or diagnosed with tuberculosis. In: Torres and Cape Tuberculosis Control Unit, editor. Cairns, Queensland,: Torres and Cape Hospital and Health Service,; 2017.

36. World Vision. Our approach to tuberculosis Daru, Papua New Guinea: World Vision; 2019 [Available from: https://www.worldvision.com.au/global-issues/work-we-do/poverty/our-approachto-tuberculosis.

37. Dooley KE, Lahlou O, Ghali I, Knudsen J, Elmessauodi MD, Cherkaoui I, Aouad RE. Risk factors for tuberculosis treatment failure, default, or relapse and outcomes of retreatment in Morocco. BMC Public Health. 2011;11(140).

38. Paul D, Busireddy, A., Nagaraja, B., Satyanarayana, S., Dewan, P.K., et al. Factors associated with delays in treatment initiation after tuberculosis diagnosis in two districts of India. PLoS ONE. 2012;7(7). 
medRxiv preprint doi: https://doi.org/10.1101/2022.01.16.22269389; this version posted January $18,2022$. The copyright holder for this preprint (which was not certified by peer review) is the author/funder, who has granted medRxiv a license to display the preprint in perpetuity.

It is made available under a CC-BY 4.0 International license.

39. Honjepari A, Madiowi S, Madjus S, Burkot C, Islam S, Chan G, et al. Implementation of screening and management of household contacts of tuberculosis cases in Daru, Papua New Guinea. Public Health Action. 2019;9(1).

40. Tefera KT, Mesfin N, Reta MM, Sisay MM, Tamirat KS, Akalu TY. Treatment delay and associated factors among adults with drug resistant tuberculosis at treatment initiating centers in the Amhara regional state, Ethiopia. BMC Infectious Diseases. 2019;19:489.

41. Divala TH, Fielding KL, Kandulu C, Nliwasa M, Sloan DJ, Gupta-Wright A, et al. Utility of broad-spectrum antibiotics for diagnosing pulmonary tuberculosis in adults: a systematic review and meta-analysis. Lancet Infectious Diseases. 2020;20(9):1089-98.

42. Storla DG, Yimer, S. \& Bjune, G.A. A systematic review of delay in the diagnosis and treatment of tuberculosis. BMC Public Health. 2008;8(15). 